\title{
Structure of the breeding bird community along the urban gradient in a town on the Zambezi River, north-eastern Namibia
}

\author{
Grzegorz Kopij $^{1,2}$ \\ ${ }^{1}$ Department of Vertebrate Zoology, \\ Wroclaw University \\ of Environmental and Life Sciences, \\ ul. Kożuchowska 5b, \\ 510631 Wrocław, Poland \\ ${ }^{2}$ Department of Integrated \\ Environmental Science, \\ Ogongo Campus, \\ University of Namibia, \\ Private Bag 5520 Oshakati, Namibia
}

\begin{abstract}
A simplified mapping method was employed to quantify avian assemblages in three study plots in a modified riparian forest on the Zambezi River in the town of Katima Mulilo, NE Namibia. The plots were arranged along the urbanization gradient: plot $\mathrm{A}$ (34 ha; $0-1 \mathrm{~km}$ from centre of the town), plot $B(27 \mathrm{ha} ; 1-2 \mathrm{~km}$ from the centre), and plot C ( $24 \mathrm{ha} ; 2-3 \mathrm{~km}$ from the centre; periphery). In total, 51 breeding bird species were recorded in all three plots. Five of them, Columba livia domestica, Passer diffusus, Pycnonotus tricolor, Streptopelia senegalensis, and Uraeginthus angolensis were classified as dominant species. The cumulative dominance was $69.9 \%$. The overall population density of all breeding species increased with the urban gradient. In general, granivorous birds were by far the most numerous feeding guild comprising $68.7 \%$ of all breeding birds. Two other guilds, frugivorous and insectivorous birds, together comprised $28.9 \%$. While the proportion of granivores decreased along the urban gradient from the town centre to its periphery, the proportion of insectivores increased. The proportion of birds nesting in/on buildings decreased, and the share of tree/shrub- and hole-nesting birds increased along the urban gradient. The diversity indices were relatively high in all plots. They decreased only slightly along the urban gradient (from the centre to the periphery). However, the Pielou's Evenness Index was comparatively low, but on a slight increase along the urbanization gradient. The Sorensen Similarity Index was low, but the values of the three studied plots were very similar.
\end{abstract}

Keywords: urban ecology, community ecology, population densities

\section{INTRODUCTION}

Urban ecology plays an increasingly important role in urban planning, nature conservation, envi-

\footnotetext{
*Corresponding author. Email: grzegorz.kopij@up.wroc.pl,
} g.kopij@unam.na ronmental education, and the so-called citizen science. It is mainly because more and more people live in cities and towns, and usually they have contact with nature through an urbanized environment. Birds are especially attractive in that regard as they are ubiquitous and occur in large numbers even in city centres. They display very interesting 
behaviour and vocalization; like humans, they are of diurnal activity and rely mainly on audiovisual cues. They are also known as good indicators of environmental quality (Kopij, 2001a; Dunn, Weston, 2008; Magle et al., 2012).

However, studies on birds in urbanized habitats are scanty in many parts of the world (Dunn, Weston, 2008; Magle et al., 2012). Compared with hundreds of urban bird atlases produced in Europe (Luniak, 2017), there are only few available in Africa (Kopij, 2001a; 2015; 2016; 2018a; 2018b). Other quantitative studies on bird assemblages in urban habitats in this region of the world are also limited, and even semi-quantitative studies were conducted in only very few towns/cities (Kopij, 2000; 2001b; 2004; 2009; 2011; 2014; Parker, 2014). Therefore, any further studies on birds in such habitats in this region are urgently needed.

The presented study reports on birds breeding along the urban gradient in one of southern African towns. The aim of the study was to show how species diversity and population densities of particular species and their dominance change in relation to the distance from the town centre. It is expected that the more urbanized the area is, the lower the diversity and the higher cumulative dominance.

\section{MATERIALS AND METHODS}

\section{Study area}

The study was conducted in the town Katima Mulilo, Zambezi Region, Namibia (Fig. 1). The town is located on the right bank of the Zambezi River. The natural vegetation, which is now highly modified by human activity, comprises the Zambezi Riparian Forest (Mendelsohn et al., 2009). Among many others, indigenous wild trees include: African teak Pterocarpus angolensis, Albizias Albizia spp., apple leave Lonchocarpus nelsii, baobab Adansonia digitata, burkea Burkea africana, bushwillows Combretum spp., camel thorn Acacia erioloba, corkwoods Commiphora spp., false mopane Guibourtia coleospermum, jackal berry Diospyros mespiliformis, knob thorn Accacia nigrescens, Makalani palm Hyphaene petersiana, manketti Schinziophyton rautanenii, marula Sclerocarya birrea, mopane Colophospermum mopane, pod mahogany Afzelia quanzensis, silver clusterleaf Terminalia sericea, sausage tree Kigelia africana, sycomore fig Ficus sycomorus, and white bauhinia Bauhinia petersiana. The most common exotic trees are gums Eucalyptus spp., jacarandas Jackaranda sp., and she-oaks Cassuarina sp.

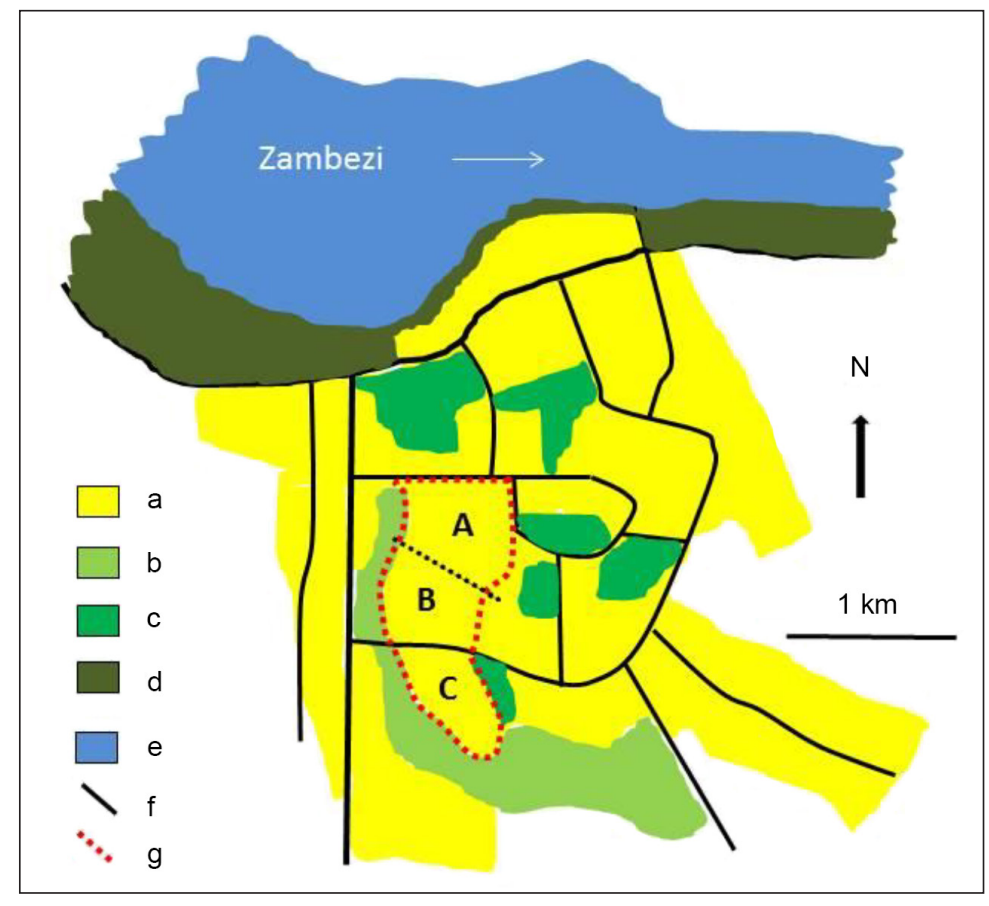

Fig. 1. Location of the study plots in the town of Katima Mulilo: a - builtup areas, b - open wetlands, c - remnant of acacia savanna, $d-$ a riparian forest, e - the Zambezi River, f - roads, $\mathrm{g}$ - study plots (A, B, C) 
Three plots were selected at different distances from the town centre (Fig. 1). Plot A (34 ha) was located 0 to $525 \mathrm{~m}$ from the centre, plot B (27 ha) 525-1050 m, and plot C (24 ha) $1050-1680 \mathrm{~m}$ from the centre. Plot A was built up in the 1950s-60s, plot B in the 1970s and 1980 s, and plot $C$ in the 1990s and the 2000s. Trees and shrubs were planted in respective periods around the buildings. In all plots, the main trees include fruit trees (mango, papayas, lemons) and such indigenous tree species as the Makalani palms, mopane, jackal berry, camel thorn, and silver tree. Most buildings are small one-storeyed houses with zinc-corrugated flat roofs surrounded by fences, often with some vegetables grown in small gardens.

The annual temperature in Katima Mulilo is $21^{\circ} \mathrm{C}$. The average maximum temperature during the hottest month (September) is $35^{\circ} \mathrm{C}$ and the average minimum temperature during the coldest month (July) is $3^{\circ} \mathrm{C}$. In the most humid month (February), the humidity is $80-90 \%$, and only $10-20 \%$ in the least humid month (September). The average annual rainfall is about $700 \mathrm{~mm}$, the highest in Namibia. Median annual rainfall is $550-600 \mathrm{~mm}$. Most of the rains fall between November and March. Figure 2 shows monthly rainfall in Katima Mulilo during the study period (2014-2015).

\section{Methods}

A simplified mapping method was employed (Bibby et al., 2012; Sutherland, 1996). Each plot was surveyed twice during the dry season (June 2014) and twice during the wet season (February-March 2015). Birds were counted along all streets. Counts were conducted in the mornings under calm and cloudless weather. At least two records of an individual showing territorial or breeding behaviour at the same site were interpreted as an occupied territory, which in most cases was equal to the number of breeding pairs. In the case of the red-billed woodhoopoe Phoeniculus purpureus or the arrowmarked babbler Turdoides jardineii, it was equal to the breeding pair and all the helpers of this pair (co-operatively breeding species), while in the case of polygynous species the number of females was taken to estimate the population density. The number of breeding pairs of the rock dove Columba livia domestica was estimated by counting all individuals roosting on roofs and dividing their number by two.

The dominance is expressed as the percentage of the total number of breeding pairs of a given species in relation to the total number of all breeding pairs of all species. Eudominant species is defined as comprising $10 \%$ and

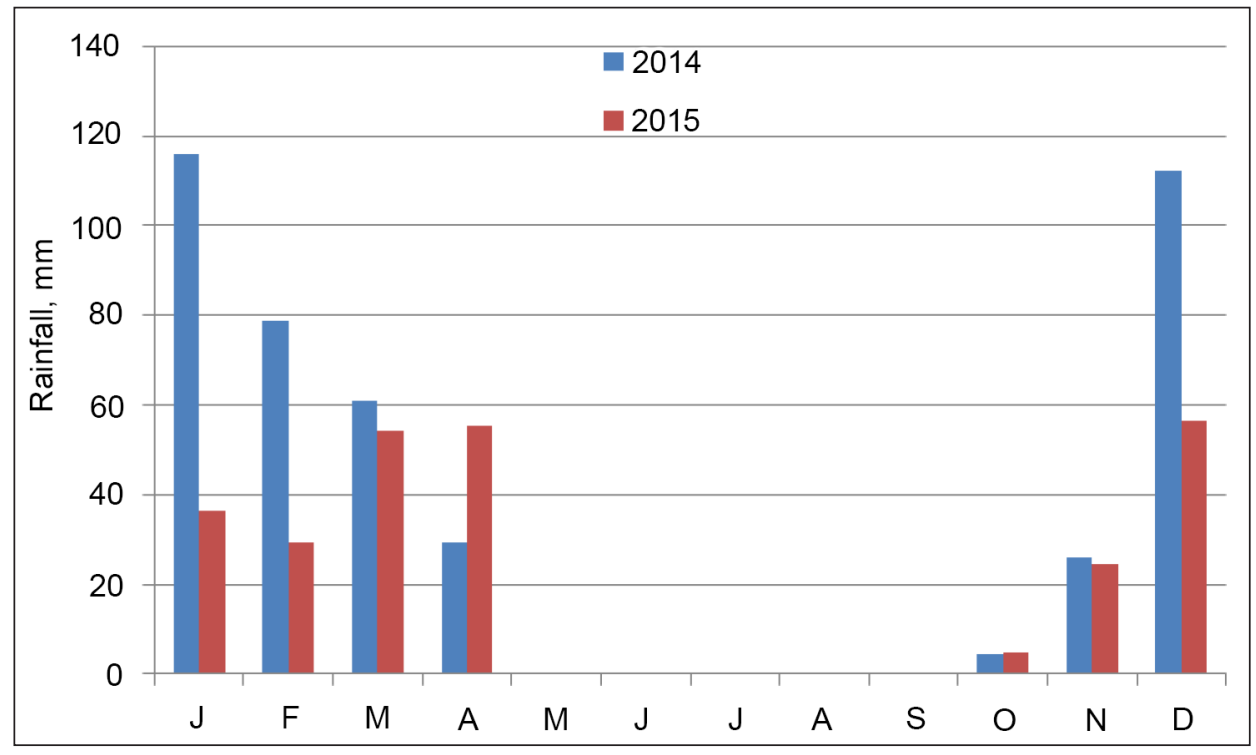

Fig. 2. Monthly rainfall in Katima Mulilo, 2014-2015 
more of all pairs of all species recorded, dominant - between 5 and $9.9 \%$, and subdominant species as comprising $2-4.99 \%$.

The following guilds were distinguished:

A. Diet: F - frugivorous, $\mathrm{G}$ - granivorous, I - insectivorous, $\mathrm{N}$ - nectarivorous, $\mathrm{O}$ - omnivorous, $\mathrm{R}$ - carnivorous; $\mathrm{B}$. Nesting: $\mathrm{B}$ - buildings, $\mathrm{H}$ - tree holes; $\mathrm{T}$ - trees or shrubs.

The following indices were used to characterize the diversity and evenness of the communities:

1) Shannon's diversity index: $\mathrm{H}^{\prime}=-\sum p_{i} \ln p_{i}$ where: $p_{i}$ is the proportion of breeding pairs belonging to the $i$ th species

2) Simpson's diversity index:

$\mathrm{D}=\left(\left(\sum n(\mathrm{n}-1)\right) / \mathrm{N}(\mathrm{N}-1)\right.$

where: $n$ - total number of breeding pairs belonging to a given species, $\mathrm{N}$ - total number of breeding pairs of all species

3) Pielou's evenness index:

$\mathrm{J}^{\prime}=\left(-\sum p_{i} \ln p_{i}\right) / \ln \mathrm{S}$

where $p_{i}$ is the proportion of breeding pairs belonging to the $i$ th species; $S$ - total number of species. J' varies between 0 and 1 . The less variation between species in a community, the higher J' is.

In addition, the community dominance index and Sörensen's coefficient were used to characterize the avian community.

1) Community dominance index:

$\mathrm{I}=\left(n_{1}+n_{2}\right) / \mathrm{N}$

where $n_{1}, n_{2}$ - number of pairs of two most abundant species, $\mathrm{N}$ - total number of pairs of all species.

2) Sörensen's coefficient:

$\mathrm{I}=2 \mathrm{C} / \mathrm{A}+\mathrm{B}$

where $A$ - the number of bird species in one plot, $\mathrm{B}$ - the number of bird species in another plot, $\mathrm{C}$ - the number of bird species common to both plots.

Systematics and the nomenclature of bird species follow Hockey et al. (2005).

\section{RESULTS AND DISCUSSION}

Fifty-one species of breeding birds were recorded in all three plots in total (App. 1). This constitutes less than $42 \%$ of all bird species recorded as breeding resident in this town (Kopij, 2016). Five of them, rock dove Columba livia domestica, grey-headed sparrow Passer diffusus, darkcapped bulbul Pycnonotus tricolor, laughing dove Streptopelia senegalensis, and blue waxbill Uraeginthus angolensis were classified as dominant species; in fact, they were eudominant, as the contribution of each of them was higher than $10 \%$. The cumulative dominance was $69.9 \%$ (Table). Only two species, the fork-tailed drongo Dicrurus adsimilis and the mourning collared-dove Streptopelia decipiens, were classified as subdominants (6.8\% combined). Both cumulative and community dominance increased with the urban gradient from the periphery to the centre, but the number of dominant species, i.e., five, remained the same (Table).

In most southern African towns and cities investigated so far, Streptopelia doves are among the most numerous bird species (Kopij, 2000; 2001a; 2001b; 2006; 2009; 2011; 2014; 2015; 2016; 2018a; 2018b). In Katima Mulilo, they comprised $22 \%$ of all breeding birds (this study). In each plot their contribution varied between 19.3\% and 24.4\% (App. 1). Four Streptopelia species were recorded as breeding in all those plots, a situation rather unusual for Namibia (Kopij, 2014) and for southern Africa in general, where two species usually occur (Kopij 2006). The overall proportion of Streptopelia-species (in all three study plots): S. senegalensis : S. capicola: S. semitorquata: $S$. decipiens was as: $0.71: 0.03: 0.06: 0.20(n=87$ breeding pairs of all dove species). The strong dominance of $S$. senegalensis is characteristic for most, if not all, towns in Namibia (Kopij, 2014; 2018a).

Two to three Passer species are recorded as common breeding residents in most southern African towns (Kopij, 2000; 2001a; 2001b; 2006; 2009; 2011; 2014; 2015; 2018b). In this study, however, only one species was recorded but it was eudominant in all study plots. In all southern African towns investigated, doves and sparrows comprise the bulk of the avian community.

The overall population density of all breeding species increased along the urban gradient. It was possible to test the differences in 
Table 1. Characterization of the breeding bird community along an urbanized gradient in Katima Mulilo, Northeast Namibia

\begin{tabular}{|c|c|c|c|c|}
\hline Parameter & Plot A & Plot B & Plot C & Plots $1+2+3$ \\
\hline \multicolumn{5}{|l|}{ Number of species and pairs } \\
\hline Number of species & 34 & 32 & 39 & 51 \\
\hline Number of breeding pairs & 184 & 117 & 96.5 & 397.5 \\
\hline Overall population density (pairs/100 ha) & 541.2 & 433.3 & 427.1 & 465.9 \\
\hline \multicolumn{5}{|l|}{ Dominance } \\
\hline Number of dominant species & 5 & 5 & 5 & 5 \\
\hline Cumulative dominance (\%) & 76.5 & 68.3 & 59.1 & 69.9 \\
\hline Community dominance (DI) & 0.42 & 0.33 & 0.33 & 0.32 \\
\hline \multicolumn{5}{|l|}{ Indices } \\
\hline Shannon's diversity index (H') & 2.44 & 2.44 & 2.67 & 2.76 \\
\hline Simpson's diversity index (D) & 0.87 & 0.90 & 0.90 & 0.90 \\
\hline Pielou's evenness index (J') & 0.69 & 0.71 & 0.73 & 0.70 \\
\hline \multicolumn{5}{|l|}{ Feeding guilds (\%) } \\
\hline Granivores & 74.6 & 62.0 & 61.5 & 68.7 \\
\hline Insectivores & 6.4 & 14.2 & 17.5 & 11.4 \\
\hline Frugivores & 15.35 & 20.9 & 17.4 & 17.5 \\
\hline Nectarivores & 2.1 & 2.2 & 1.5 & 2.0 \\
\hline Carnivores & 0.3 & 0.4 & 0.5 & 0.4 \\
\hline \multicolumn{5}{|l|}{ Nesting guilds (\%) } \\
\hline Trees/shrubs & 49.3 & 68.5 & 65.3 & 59.1 \\
\hline Holes & 6.3 & 6.9 & 9.2 & 7.2 \\
\hline Buildings & 43.9 & 24.7 & 24.9 & 33.8 \\
\hline
\end{tabular}

population densities between the three study plots for six bird species statistically ( $x^{2}$-test; expected values larger than five; $d f=2$ ). Only population densities of the red-eyed dove were different $\left(x^{2}=31.2 ; p<0.01\right)$, while the differences were statistically insignificant for all the other species, namely: grey-headed sparrow $\left(x^{2}=4.4 ; p>0.05\right)$, dark-eyed bulbul $\left(x^{2}=0.7 ; p>0.05\right)$, Cape turtle-dove $\left(x^{2}=1.4\right.$; $p>0.05)$, blue waxbill $\left(x^{2}=0.3 ; p>0.05\right)$, and mourning dove $\left(x^{2}=0.02 ; p>0.05\right)$.

In overall, granivorous birds were by far the most numerous feeding guild comprising over $68.7 \%$ of all breeding birds. Such a situation is characteristic of urban habitats (Chace, Walsh, 2006). Two other guilds, frugivorous and insectivorous birds, comprised together additional 28.9\% (Table). The contribution of all other guilds was much lower (together 2.5\%). While the proportion of the granivores has decreased along the urban gradient from the town centre to its periphery, that of insectivores increased. The proportion of the birds nesting in/on building decreased, and that of tree/shrub- and holenesting birds increased along the urban gradient (Table). The G-test shows that the differences for granivores, insectivores, and frugivores were statistically highly significant.

The diversity indices were relatively high in all plots. They only slightly decreased along the urban gradient (from the centre to the periphery). However, the Pielou's Evenness Index was comparatively low, but it was on a slight increase along the urbanization gradient (Table). The Sörensen Similarity Index was low, but of a very similar value between the three studied 
plots $(\mathrm{I}=0.36$ between plot $\mathrm{A}$ and plot $\mathrm{B}, \mathrm{I}=0.37$ between plot $\mathrm{A}$ and plot $\mathrm{C}$, and $\mathrm{I}=0.34$ between plot B and plot C).

\section{CONCLUSIONS}

Contrary to expectations, no significant changes were recorded in the number of species and diversity evenness indices in avian community along the urbanization gradient. Also, population densities of more numerous birds did not change significantly along this gradient as only the proportions of main feeding and nesting guilds changed significantly along this gradient. More profound changes along the urban gradient in avian communities are expected to exist in larger cities, but this premise requires further investigations.

Appendix. Residential area along an urbanization gradient in Katima Mulilo, NE Namibia. A - close to the centre ( $34 \mathrm{ha}), \mathrm{B}$ - at mid-distance from the centre $(27 \mathrm{ha}), \mathrm{C}$ - far from the centre $(24 \mathrm{ha})$; $\mathrm{N}$ - number of pairs, $\mathrm{d}$ - density (pairs/10 ha), $\mathrm{D}$ - dominance (\%). Abbreviations for guilds: feeding: $\mathrm{F}$ - frugivorous, $\mathrm{G}$ - granivorous, $\mathrm{I}$ - insectivorous, $\mathrm{N}$ - nectarivorous, $\mathrm{O}$ - omnivorous, $\mathrm{R}$ - carnivorous; nesting: $\mathrm{B}$ - buildings, $\mathrm{H}$ - tree holes; $\mathrm{T}$ - trees or shrubs. Dominant species are indicated in bold type.

\begin{tabular}{|c|c|c|c|c|c|c|c|c|c|c|c|c|c|c|}
\hline \multirow[t]{2}{*}{ Species } & \multicolumn{2}{|c|}{ Guilds } & \multicolumn{3}{|c|}{ Number of pairs } & \multicolumn{3}{|c|}{ Pairs/10 ha } & \multicolumn{3}{|c|}{ Dominance (\%) } & \multicolumn{3}{|c|}{ All plots $(1+2+3)$} \\
\hline & Feed & Nest & $\mathrm{A}$ & B & $\mathrm{C}$ & $\mathrm{A}$ & B & $\mathrm{C}$ & A & B & $\mathrm{C}$ & $\mathrm{N}$ & d & $\mathrm{D}$ \\
\hline $\begin{array}{c}\text { Amadina erythro- } \\
\text { cephala }\end{array}$ & G & $\mathrm{T}$ & 1 & 0 & 0 & 0.3 & 0.0 & 0.0 & 0.5 & 0 & 0 & 1 & 0.1 & 0.3 \\
\hline Bubalornis niger & G & $\mathrm{T}$ & 1 & 0 & 1 & 0.3 & 0.0 & 0.4 & 0.5 & 0 & 1 & 2 & 0.2 & 0.5 \\
\hline Campethera abingoni & $\mathrm{I}$ & $\mathrm{H}$ & 0 & 0 & 0.5 & 0.0 & 0.0 & 0.2 & 0 & 0 & 0.5 & 0.5 & 0.1 & 0.1 \\
\hline $\begin{array}{c}\text { Centropus supercil- } \\
\text { iosus }\end{array}$ & I & $\mathrm{T}$ & 0 & 0 & 0.5 & 0.0 & 0.0 & 0.2 & 0 & 0 & 0.5 & 0.5 & 0.1 & 0.1 \\
\hline $\begin{array}{c}\text { Chalcomitra senega- } \\
\text { lensis }\end{array}$ & $\mathrm{N}$ & $\mathrm{T}$ & 1 & 1 & 0 & 0.3 & 0.4 & 0.0 & 0.5 & 0.9 & 0 & 2 & 0.2 & 0.5 \\
\hline $\begin{array}{c}\text { Chlorocichla flaviven- } \\
\text { tris }\end{array}$ & $\mathrm{F}$ & $\mathrm{T}$ & 0 & 0 & 0.5 & 0.0 & 0.0 & 0.2 & 0 & 0 & 0.5 & 0.5 & 0.1 & 0.1 \\
\hline $\begin{array}{c}\text { Chlorophoneus sulfu- } \\
\text { reopectus }\end{array}$ & $\mathrm{F}$ & $\mathrm{T}$ & 0 & 0.5 & 0.5 & 0.0 & 0.2 & 0.2 & 0 & 0.4 & 0.5 & 1 & 0.1 & 0.3 \\
\hline Cinnyris mariquensis & $\mathrm{N}$ & $\mathrm{T}$ & 3 & 0.5 & 1 & 0.9 & 0.2 & 0.4 & 1.6 & 0.4 & 1 & 4.5 & 0.5 & 1.1 \\
\hline Cinnyris talatala & $\mathrm{N}$ & $\mathrm{T}$ & 0 & 1 & 0 & 0.0 & 0.4 & 0.0 & 0 & 0.9 & 0 & 1 & 0.1 & 0.3 \\
\hline $\begin{array}{c}\text { Columba livia do- } \\
\text { mestica }\end{array}$ & G & B & 47 & 10 & 6 & 13.8 & 3.7 & 2.5 & 25.5 & 8.5 & 6.2 & 63 & 7.4 & 15.8 \\
\hline Coracias caudatus & I & $\mathrm{H}$ & 0.5 & 1 & 1 & 0.1 & 0.4 & 0.4 & 0.3 & 0.9 & 1 & 2.5 & 0.3 & 0.6 \\
\hline Corvus albus & $\mathrm{O}$ & $\mathrm{T}$ & 1.5 & 0.5 & 1 & 0.4 & 0.2 & 0.4 & 0.8 & 0.4 & 1 & 3 & 0.4 & 0.8 \\
\hline $\begin{array}{l}\text { Corythaixoides con- } \\
\text { color }\end{array}$ & $\mathrm{F}$ & $\mathrm{T}$ & 0 & 0.5 & 1 & 0.0 & 0.2 & 0.4 & 0 & 0.4 & 1 & 1.5 & 0.2 & 0.4 \\
\hline Cossypha heuglini & I & $\mathrm{T}$ & 1 & 1 & 0.5 & 0.3 & 0.4 & 0.2 & 0.5 & 0.9 & 0.5 & 2.5 & 0.3 & 0.6 \\
\hline Cypsiurus parvus & I & $\mathrm{T}$ & 1 & 4 & 3 & 0.3 & 1.5 & 1.3 & 0.5 & 3.4 & 3.1 & 8 & 0.9 & 2 \\
\hline Dicrurus adsimilis & I & $\mathrm{T}$ & 2.5 & 2.5 & 5 & 0.7 & 0.9 & 2.1 & 1.4 & 2.1 & 5.2 & 10 & 1.2 & 2.5 \\
\hline Dryoscopus cubla & I & $\mathrm{T}$ & 0.5 & 0.5 & 0 & 0.1 & 0.2 & 0.0 & 0.3 & 0.4 & 0 & 1 & 0.1 & 0.3 \\
\hline Glaucidium perlatum & I & $\mathrm{H}$ & 1 & 0 & 0 & 0.3 & 0.0 & 0.0 & 0.5 & 0 & 0 & 1 & 0.1 & 0.3 \\
\hline Halcyon senegalensis & I & $\mathrm{H}$ & 1 & 0 & 0 & 0.3 & 0.0 & 0.0 & 0.5 & 0 & 0 & 1 & 0.1 & 0.3 \\
\hline Hedydipna collaris & $\mathrm{N}$ & $\mathrm{T}$ & 0 & 0 & 0.5 & 0.0 & 0.0 & 0.2 & 0 & 0 & 0.5 & 0.5 & 0.1 & 0.1 \\
\hline
\end{tabular}


Appendix. (continued)

\begin{tabular}{|c|c|c|c|c|c|c|c|c|c|c|c|c|c|c|}
\hline \multirow[t]{2}{*}{ Species } & \multicolumn{2}{|c|}{ Guilds } & \multicolumn{3}{|c|}{ Number of pairs } & \multicolumn{3}{|c|}{ Pairs/10 ha } & \multicolumn{3}{|c|}{ Dominance (\%) } & \multicolumn{3}{|c|}{ All plots $(1+2+3)$} \\
\hline & Feed & Nest & A & B & $\mathrm{C}$ & A & B & $\mathrm{C}$ & A & B & $\mathrm{C}$ & $\mathrm{N}$ & d & $\mathrm{D}$ \\
\hline Hirundo smithii & I & B & 2 & 2 & 2 & 0.6 & 0.7 & 0.8 & 1.1 & 1.7 & 2.1 & 6 & 0.7 & 1.5 \\
\hline Indicator indicator & I & $\mathrm{T}$ & 0 & 0 & 0.5 & 0.0 & 0.0 & 0.2 & 0 & 0 & 0.5 & 0.5 & 0.1 & 0.1 \\
\hline Lamprotonis australis & $\mathrm{F}$ & $\mathrm{H}$ & 3 & 2 & 1 & 0.9 & 0.7 & 0.4 & 1.6 & 1.7 & 1 & 6 & 0.7 & 1.5 \\
\hline Lamprotornis nitens & $\mathrm{F}$ & $\mathrm{H}$ & 3 & 0.5 & 2 & 0.9 & 0.2 & 0.8 & 1.6 & 0.4 & 2.1 & 5.5 & 0.6 & 1.4 \\
\hline Laniarius bicolor & I & $\mathrm{T}$ & 0 & 0 & 0.5 & 0.0 & 0.0 & 0.2 & 0 & 0 & 0.5 & 0.5 & 0.1 & 0.1 \\
\hline Laniarius major & I & $\mathrm{T}$ & 0 & 0 & 0.5 & 0.0 & 0.0 & 0.2 & 0 & 0 & 0.5 & 0.5 & 0.1 & 0.1 \\
\hline Lonchura cucculata & G & $\mathrm{T}$ & 0.5 & 0 & 0.5 & 0.1 & 0.0 & 0.2 & 0.3 & 0 & 0.5 & 1 & 0.1 & 0.3 \\
\hline Lybius torquatus & $\mathrm{F}$ & $\mathrm{H}$ & 1 & 0 & 1 & 0.3 & 0.0 & 0.4 & 0.5 & 0 & 1 & 2 & 0.2 & 0.5 \\
\hline Merops pusilus & I & $\mathrm{H}$ & 0 & 0 & 0.5 & 0.0 & 0.0 & 0.2 & 0 & 0 & 0.5 & 0.5 & 0.1 & 0.1 \\
\hline Milvus aegyptius & $\mathrm{R}$ & $\mathrm{T}$ & 0.5 & 0.5 & 0.5 & 0.1 & 0.2 & 0.2 & 0.3 & 0.4 & 0.5 & 1.5 & 0.2 & 0.4 \\
\hline Motacilla aguimp & I & B & 1 & 0 & 0 & 0.3 & 0.0 & 0.0 & 0.5 & 0 & 0 & 1 & 0.1 & 0.3 \\
\hline Nilaus afer & I & $\mathrm{T}$ & 0 & 1 & 0 & 0.0 & 0.4 & 0.0 & 0 & 0.9 & 0 & 1 & 0.1 & 0.3 \\
\hline Oena capensis & G & $\mathrm{T}$ & 0.5 & 0 & 0.5 & 0.1 & 0.0 & 0.2 & 0.3 & 0 & 0.5 & 1 & 0.1 & 0.3 \\
\hline Passer diffusus & G & B & 31 & 17 & 16 & 9.1 & 6.3 & 6.7 & 16.8 & 14.5 & 16.6 & 64 & 7.5 & 16.1 \\
\hline Phoeniculus purpureus & I & $\mathrm{H}$ & 0 & 1 & 0 & 0.0 & 0.4 & 0.0 & 0 & 0.9 & 0 & 1 & 0.1 & 0.3 \\
\hline Ploceus velatus & G & $\mathrm{T}$ & 2 & 0 & 1 & 0.6 & 0.0 & 0.4 & 1.1 & 0 & 1 & 3 & 0.4 & 0.8 \\
\hline Ploceus xanthopterus & G & $\mathrm{T}$ & 0 & 1 & 0 & 0.0 & 0.4 & 0.0 & 0 & 0.9 & 0 & 1 & 0.1 & 0.3 \\
\hline Poicephalus meyeri & $\mathrm{F}$ & $\mathrm{H}$ & 1 & 1 & 0.5 & 0.3 & 0.4 & 0.2 & 0.5 & 0.9 & 0.5 & 2.5 & 0.3 & 0.6 \\
\hline Pycnonotis tricolor & F & $\mathrm{T}$ & 19 & 19 & 9 & 5.6 & 7.0 & 3.8 & 10.3 & 16.2 & 9.3 & 47 & 5.5 & 11.8 \\
\hline $\begin{array}{l}\text { Rhinopomastus cy- } \\
\text { anomelas }\end{array}$ & I & $\mathrm{H}$ & 0 & 0.5 & 0 & 0.0 & 0.2 & 0.0 & 0 & 0.4 & 0 & 0.5 & 0.1 & 0.1 \\
\hline Streptopelia capicola & G & $\mathrm{T}$ & 1.5 & 1 & 0.5 & 0.4 & 0.4 & 0.2 & 0.8 & 0.9 & 0.5 & 3 & 0.4 & 0.8 \\
\hline Streptopelia decipiens & G & $\mathrm{T}$ & 6 & 5.5 & 5.5 & 1.8 & 2.0 & 2.3 & 3.3 & 4.7 & 5.7 & 17 & 2.0 & 4.3 \\
\hline $\begin{array}{c}\text { Streptopelia semi- } \\
\text { torquata }\end{array}$ & G & $\mathrm{T}$ & 2 & 2 & 1 & 0.6 & 0.7 & 0.4 & 1.1 & 1.7 & 1 & 5 & 0.6 & 1.3 \\
\hline $\begin{array}{c}\text { Streptopelia senega- } \\
\text { lensis }\end{array}$ & G & $\mathrm{T}$ & 26 & 20 & 16 & 7.6 & 7.4 & 6.7 & 14.1 & 17.1 & 16.6 & 62 & 7.3 & 15.6 \\
\hline Tauraco schalowi & $\mathrm{F}$ & $\mathrm{T}$ & 0.5 & 0 & 0.5 & 0.1 & 0.0 & 0.2 & 0.3 & 0 & 0.5 & 1 & 0.1 & 0.3 \\
\hline Terpsiphone viridis & I & $\mathrm{H}$ & 1.5 & 2 & 2.5 & 0.4 & 0.7 & 1.0 & 0.8 & 1.7 & 2.6 & 6 & 0.7 & 1.5 \\
\hline Turdoides jardineii & I & $\mathrm{T}$ & 0 & 1 & 0 & 0.0 & 0.4 & 0.0 & 0 & 0.9 & 0 & 1 & 0.1 & 0.3 \\
\hline Turtur afer & G & $\mathrm{T}$ & 0 & 0 & 0.5 & 0.0 & 0.0 & 0.2 & 0 & 0 & 0.5 & 0.5 & 0.1 & 0.1 \\
\hline $\begin{array}{c}\text { Uraeginthus ango- } \\
\text { lensis }\end{array}$ & G & $\mathrm{T}$ & 18 & 14 & 16 & 5.3 & 5.2 & 6.7 & 9.8 & 12 & 10.4 & 42 & 4.9 & 10.6 \\
\hline Urocolius indicus & $\mathrm{F}$ & $\mathrm{T}$ & 1 & 1 & 1 & 0.3 & 0.4 & 0.4 & 0.5 & 0.9 & 1 & 3 & 0.4 & 0.8 \\
\hline Vidua chalybeata & G & $\mathrm{T}$ & 1 & 2 & 1 & 0.3 & 0.7 & 0.4 & 0.5 & 1.7 & 1 & 4 & 0.5 & 1 \\
\hline Total & & & 184 & 117 & 96.5 & 54.1 & 43.3 & 42.7 & 100 & 100 & 100 & 397.5 & 46.8 & 100 \\
\hline
\end{tabular}




\section{References}

1. Bibby CJ, Burgess ND, Hill DA. Bird censuses techniques. Academic Press: London; 2012.

2. Chace JF, Walsh JJ. Urban effects on native avifauna: a review. Landscape Urban Plan. 2006; 74: 46-69.

3. Dunn AM, Weston MA. Review of terrestrial bird atlases of the world and their application. Emu. 2008; 108: 42-67.

4. Hockey PAR, Dean WRJ, Ryan PG, Maree S, editors. Roberts' birds of Southern Africa. Cape Town: John Voelcker Bird Book Fund; 2005.

5. Kopij G. Birds of Maseru. NUL J Res (Roma, Lesotho), 2000; 8: 104-51.

6. Kopij G. Atlas of birds of Bloemfontein. Roma. (Lesotho)/Bloemfontein (RSA): Department of Biology, National University of Lesotho/ Free State Bird Club; 2001a.

7. Kopij G. Birds of Roma Valley, Lesotho. Roma (Lesotho): Department of Biology, National University of Lesotho; 2001b.

8. Kopij G. Bird communities of a suburb habitat in South African Highveld during the wet and dry season. Zeszyty Naukowe AR Wrocław, Zootechnika, 2004; 50: 205-11.

9. Kopij G. The structure of assemblages and dietary relationships in birds in South African grasslands. Wrocław: Wydawnictwo Akademii Rolniczej we Wrocławiu; 2006. 128 p.

10. Kopij G. Quantitative studies on birds breeding in Ladybrand, eastern Free State, South Africa. Zeszyty Nukowe UP we Wrocławiu, Biologia i Hodowla Zwierząt, 2009; 58: 121-7.
11. Kopij G. Avian diversity in ruderal and urbanized habitats in Lesotho. Berkut, 2011;20(1/2): 22-28.

12. Kopij G. Avian assemblages in urban habitats in North-central Namibia. ISTJ N. 2014; 3(1): 64-81.

13. Kopij G. Avian diversity in an urbanized South African grassland. Zoology Ecology. 2015; 25(2): 87-100.

14. Kopij G. Birds of Katima Mulilo town, Zambezi Region, Namibia. ISTJN. 2016; 7: 85-102.

15. Kopij G. 2018a. Provisional atlas of breeding birds of Swakopmund in the coastal Namib Desert. Lanioturdus. 51(2): 2-12.

16. Kopij G. 2018b. Atlas of birds of Kasani. Babbler. 64: 3-15.

17. Luniak M. Urban ornithological atlases in Europe: a review. In: Murgui E., Hedblom H, editors. Ecology and conservation of birds in urban environments. Heidelberg: Springer; 2017; 209-23.

18. Magle SB, Hunt VM, Vernon M, Crooks KR. Urban wildlife research: past, present, and future. Biological Conservation. 2012; 155 : 23-32.

19. Mendelsohn J, Jarvis A, Roberts C, Robertson T. Atlas of Namibia. A portrait of the land and its people. Cape Town: Sunbird Publishers; 2009.

20. Parker V. The birds of the Groenkloof conservation Complex, Pretoria. Orn. Observ. 2014; 5: $81-100$.

21. Sutherland WJ. Ecological Census Techniques: a handbook. Cambridge University Press, Cambridge (U.K.), 1996. 


\section{Grzegorz Kopij}

PERINČIŲ PAUKŠČIŲ BENDRUOMENĖS ŠIAURĖS RYTŲ NAMIBIJOS MIESTE PRIE ZAMBEZĖS UPE்S

Santrauka

Taikant paprastą kartografavimo metodą, buvo ìvertintas paukščiu populiacijos kiekis trijuose sklypuose Katima Mulilo mieste, modifikuotame pakrantès miške prie Zambezès upès (Šiaurès rytų Namibija). Sklypai buvo išdestyti urbanizacijos kryptimi: A sklypas (34 ha; $0-1 \mathrm{~km}$ nuo miesto centro), B sklypas (27 ha; 1-2 km nuo centro) ir C sklypas (24 ha; $2-3 \mathrm{~km}$ nuo centro; pakraštyje). Iš viso šiuose sklypuose užregistruota 51 perinčių paukščių rūšis. Penkios iš jų: Columba livia domestica, Passer diffusus, Pycnonotus tricolor, Streptopelia senegalensis ir Uraeginthus angolensis buvo klasifikuojamos kaip dominuojančios rūšys. Bendras dominavimas - 69,9\%. Bendras visu pe- rinčių paukščių populiacijos tankis didejjo urbanizacijos gradiento kryptimi. Apskritai grūdus lesančių paukščių populiacija buvo viena iš gausiausių ir apèmé 68,7 \% visų perinčių paukščių. Kitos populiacijos, vaisiaèdžiai ir vabzdžiaèdžiai, sudare 28,9 \%. Grūdus lesančiu paukščiu populiacija nuo miesto centro iki pakraščio mažèjo, vabzdžiaèdžių - didejjo. Ant pastatų lizdus sukančių paukščių dalis mažèjo, o medžiuose, krūmuose ir kiaurymèse lizdus sukančių paukščių dalis didèjo priklausomai nuo miesto urbanizacijos krypties (nuo centro $\mathfrak{i}$ pakraščius). Itvairovès indeksai buvo aukšti visose srityse. Jie nepastebimai mažèjo priklausomai nuo miesto urbanizacijos krypties (nuo centro i pakraščius). Gana žemas Pielou tolygumo rodiklis šiek tiek didejo priklausomai nuo urbanizacijos krypties. Sorensen panašumo indeksas buvo žemas, labai panašus ị kitų tirtų sričių.

Raktažodžiai: miesto ekologija, bendruomenès ekologija, populiacijos tankumas 